\title{
Anthós
}

2014

Girl Power: The Episcopate and Female Agency in the Central Middle Ages

Jackie Brooks

Portland State University

Follow this and additional works at: https://pdxscholar.library.pdx.edu/anthos

Part of the Medieval History Commons, and the Women's History Commons Let us know how access to this document benefits you.

Recommended Citation

Brooks, Jackie (2014) "Girl Power: The Episcopate and Female Agency in the Central Middle Ages," Anthós: Vol. 6: Iss. 1, Article 13.

https://doi.org/10.15760/anthos.2014.215

This open access Article is distributed under the terms of the Creative Commons Attribution-NonCommercialShareAlike 4.0 International License (CC BY-NC-SA 4.0). All documents in PDXScholar should meet accessibility standards. If we can make this document more accessible to you, contact our team. 


\section{Girl Power: The Episcopate and Female Agency in the Central Middle Ages}

Jackie Brooks

In 1076, Henry IV, King of Germany (1056-1106), convened a synod of bishops with the intention of denouncing and deposing Pope Gregory VII (1073-85) in response to the latter's actions after the Lenten Synod of $1075 .^{1}$ A majority of the German bishops present, allied with Henry, produced a letter to Gregory in which they renounced the method of his ascension to the papacy, as well as the methods he employed to achieve the reform he sought. In one passage, they particularly renounced Gregory's well-known close relationships with several powerful women. ${ }^{2}$ The complaints of the bishops revolve around the belief that these women exerted an inordinate amount of influence in service of Gregory's pontificate. They stated, "In this affair, our sense of decency is affected ... although the general complaint is sounded everywhere, that all judgments and all decrees are enacted by women in the Apostolic see, and ultimately that the whole orb of the Church is administered by this new senate of women." ${ }^{3}$ While this remonstrance of Gregory's

${ }^{1}$ Gregory issued an edict against lay investiture and excommunicated five of Henry's bishops for simony. See Uta-Renate Blumenthal, The Investiture Controversy: Church and Monarchy from the Ninth to the Twelfth Century (Philadelphia, University of Pennsylvania Press: 1988), 119.

${ }^{2}$ Beatrice of Tuscany, her daughter Matilda of Tuscany, and Henry's mother, the Empress-Dowager Agnes of Poitiers.

${ }^{3}$ Siegfried, Archbishop of Mainz, et al. "Renunciation of Gregory VII by the German Bishops (Synod of Worms, 1076)," in Imperial Lives and Letters of the Eleventh Century, trans. Theodore E. Mommsen and Karl F. Morrison (New York: Columbia University Press, 2000), 149. 
friendships with women follows the generally misogynist views common during the period, there is evidence that the clergy of the Middle Ages were more aware of the power held by many of the noble laywomen of Europe than they perhaps would have wanted to admit. Evidence to this effect can be found in the many extant letters from high ranking clergymen, primarily bishops and popes, to a variety of noble women, in which these women are regularly called upon to support the Church in many ways. Joan Ferrante found "the letters show that women's authority, political and intellectual, is recognized by the men who work with them, that women collaborate and cooperate with men in politics, religion, and scholarship as colleagues, that their friendship and support is valued and trusted." ${ }^{4}$ What will be examined here are the ways in which several members of the clergy of the eleventh and twelfth centuries not only recognized that women had access to power and influence, but that these bishops commonly worked to access this power for the support of the political agenda of the Church.

The power that noble laywomen were capable of wielding during the Central Middle Ages had a great deal to do with the laws related to property. In the previous period, as the empire of Charlemagne began to "lose its cohesion," the predominance of the great noble families with vast amounts of landed property began to eclipse the authority of the monarchy. ${ }^{5}$ Furthermore, there were few serious restrictions to the inheritance of female offspring, due to a relaxation of inheritance laws during the sixth and seventh centuries. ${ }^{6}$ As Jo Ann McNamara and Suzanne Wemple point out in their study of female power in the sixth through the twelfth centuries, "few families were

${ }^{4}$ Joan M. Ferrante, To the Glory of Her Sex: Women's Roles in the Composition of Medieval Texts (Bloomington: Indiana University Press, 1997), 10.

5 Jo Ann McNamara and Suzanne Wemple, "The Power of Women Through the Family in Medieval Europe: 500-1100,” Feminist Studies 1, no. 3/4 (1973): 133.

${ }^{6}$ Ibid., 131. 
inclined to exclude their daughters from the capacity to inherit allodial land. When such land came into the hands of a woman, it remained her property and did not pass to her husband or her husband's family unless she willed it to do so."7 Despite a woman's capacity to keep control of her own land after marriage, such women were still highly desirable as marriage partners for the sons of other powerful noble families, and as such it was possible that a woman's property could increase exponentially through marriage. When her husband was away from home, or as often happened in this violent and dangerous period, died from illness or in battle, his wife effectively took his place. Sometimes she did this together with any adult male sons, but often completely on her own. ${ }^{8}$ As a good illustration of this, one need only look at one of the letters sent to Adela of Blois from her husband Count Stephen of Blois, away on crusade. At the end of a long letter addressed to Adela and their children, as well as all of his vassals, Stephen closes the letter in a way that makes it clear that Adela is in charge while he is away: "I charge you to do right, to carefully watch over your land, to do your duty as you ought to your children and your vassals." "9 By referring to the land, the children, and the vassals as belonging to Adela in this very public letter, Stephen ensures that Adela's authority cannot be challenged while he is gone. Again from McNamara and Wemple, "Wherever we look during this period, we find no really effective barriers to the capacity of women to exercise power. They appear as military leaders, judges, castellans, controllers of property. Though barred from the priesthood, they even exercised vast power over the church as a result of their family positions." 10 As we shall see, the

7 Ibid., 134.

${ }^{8}$ Kimberly LoPrete, “Noble Women,” in Women and Gender in Medieval Europe, an Encyclopedia (New York: Routledge, 2006), 609.

${ }^{9}$ Stephen of Blois to Adela, Epistolae, http://epistolae.ccnmtl.columbia.edu/ letter/79.html.

${ }^{10}$ McNamara and Wemple, “The Power of Women,” 136. 
power women had, as regards the Church, was not only related to the possibility of inheriting the rights to the administration of Church lands and property. Female power was also wielded in their social networks as wives and mothers of powerful men, and as influential members of the greater community.

One of the primary means through which bishops of the Central Middle Ages would work to influence others to their cause was in the writing of letters. Due to the way letters were handled and disseminated, we still have access to many of them today. Written in Latin, these types of letters were meant to be public and were often read aloud, not only to the recipient, but also to the court or circle of the recipient, and then were kept in archives or letter collections. ${ }^{11}$ While most of the letters we have which were to or from women were to royal or aristocratic women, there exists a significant collection of correspondence to religious women as well (such as abbesses). For the purposes of this study, however, we will focus on the nobility (empresses, queens, countesses, and duchesses). It must be noted, however, that since many noble women chose to enter religious communities later in life, there is frequently cross-over between the two groups. ${ }^{12}$

There is a great deal of evidence that medieval letter writing was more than just a means of communicating information over distance, but also was used as a political tool. As I. S. Robinson points out in his 1978 study of the friendship networks of Gregory VII:

...not the least important aspect of the friendship networks of twelfth-century intellectuals was the co-ordinated use of letters in a moment of crisis to persuade eminent personages to pursue a particular course of action ... It is no exaggeration to say that [Gregory's] principal instrument for

${ }^{11}$ Joan Ferrante, "Letter Writing," in Women and Gender in Medieval Europe, an Encyclopedia (New York: Routledge, 2006), 467. 
the enforcement of reform was the political pressure which he could exert through his friendship network and which he could direct by means of letters. ${ }^{13}$

And Gregory certainly wasn't alone in the employment of this methodology, nor was this solely a tool of the clergy. However, in the letters specifically to and from women, the vast majority of their correspondence with particular individuals were with members of the episcopate. As a resource for the study of women in the Middle Ages, these letters not only show the extensive involvement of women in the public life of their society, ${ }^{14}$ but also reveal the ways in which the members of the clergy who wrote to them utilized vocabulary acknowledging women's influence and power, and emphasized that this was work they should do on behalf of the Church, and for God. These letters were calling noble women to service, and they were often couched in words of love.

One type of service that bishops asked of noble women was that of utilizing their influence on their husbands. Women had long served as mediators between men in times of conflict, so their abilities to be persuasive were widely accepted. There are several examples of the clergy encouraging women to use their persuasive powers to influence their husbands in the many letters from bishops to noble laywomen which have survived. One such letter, surprisingly enough, was from the monk, Peter Damian. As Damian's misogynistic views of women are well known, ${ }^{15}$ it is somewhat surprising to discover any writings in which he gives a woman praise, and especially in which he gives one credit for her ability to influence her family to better behavior. In

${ }^{12}$ LoPrete, "Noble Women,” 610.

${ }^{13}$ I. S. Robinson, "The Friendship Network of Gregory VII,” History 63, no. 207 (1978): 9.

${ }^{14}$ Ferrante, "Letter Writing," 467.

${ }^{15}$ Carl R. Triebs, "About Celibacy, I Have No Instructions From the Lord": An Inquiry Into the Origins of Clerical Celibacy (Victoria, BC: Trafford, 2004), 75. 
1066 in a letter to Guilla, the Countess of Monte Santa Maria, Damian writes to encourage her to correct the actions of her husband's family, whom he accuses of having "a corrupted law of living."

But clearly we do not deny that since the turning of a woman to her husband was divinely decreed, the weaker sex for the most part requires manly authority. But when a woman judges more rightly, it is suitable that a man/husband not oppose her by the laws of his authority. Truly this is a judgment for man, not against man. ${ }^{16}$

In one short passage, Damian expresses both what he felt to be the lesser station of women in general, while at the same time acknowledging the ability of women to have an influence for the betterment of man. Similarly, two letters written by Pope Gregory VII, in 1074 and 1080 respectively, were to Matilda of Flanders, wife to the King of England William I (1066-87). Gregory is writing in response to letters he received from the queen (now lost) praising her love of God and encouraging her to inspire her husband. In the first:

Be instant with your husband; do not cease from suggesting things profitable for his soul. For it is certain that, if as the Apostle says an unbelieving husband is saved by a believing wife, even a believing husband is increased for the better by a believing wife. ${ }^{17}$

In the second letter Gregory states, "With these weapons and ones like them do not cease from arming your husband whenever God

${ }^{16}$ Peter Damian to Gilla, Epistolae. http://epistolae.ccnmtl.columbia.edu/ letter/1199.html.

${ }^{17}$ Gregory VII to Matilda of Flanders, 1.71, in The Register of Pope Gregory VII (Oxford: Oxford University Press, 2002), trans. H. E. J. Cowdrey, 75. See Cowdrey's notes for biblical references. 
shall give you an opportunity."18 Gregory's messages to Matilda assure her that she holds the power to affect her husband's relationships, not only with the pope, but also with God. The words "saving" and "arming" suggest that Matilda is being called to heroic action to the redemption of her husband, and the word "suggesting" tells her how to accomplish the deed. Similarly, to Adelaide of Swabia, Queen of Hungary, Gregory wrote, "you should always be at pains to attract the mind of your lord the king ... to the fear and love of God, and to be of benefit to holy church according to your power ..."19 Again Gregory emphasizes that this is work ("be at pains"), and that the queen has the "power."

Another noblewoman who received many appeals from the episcopate to influence her husband was Matilda of Scotland, the Queen of England. Early in the twelfth century, Matilda's husband, King Henry I (1100-1135), was in conflict with Anselm, Archbishop of Canterbury (1093-1109) over the question of lay investiture. This conflict, known as the English Investiture Controversy, resulted in a lengthy exile of Anselm from England between 1103 and 1106. ${ }^{20}$ In one letter prior to this exile, in 1102, Anselm wrote to Matilda regarding the worsening relationship between himself and her husband, and stated, "I also pray that [God] may cause your good intention to progress in such a way that through you the heart of our lord the King may turn away from 'the counsel of princes' which the Lord rejects and be made to follow God's counsel 'which stands firm for ever." ${ }^{21}$ In 1104, in a letter Matilda wrote to Anselm, she stated, "With God's help and my suggestions, as far as I am able, [Henry]

${ }^{18}$ Register, 7.26, trans. Cowdrey, 357-358.

${ }^{19}$ Ibid., 8.22, 396.

${ }^{20}$ Sally Vaughn, St. Anselm and the Handmaidens of God: A Study of Anselm's Correspondence with Women (Turnhout, Belgium: Brepols, 2002), 206.

${ }^{21}$ Anselm of Canterbury to Matilda, 246, in The Letters of Saint Anselm of Canterbury, 3 vols., trans. Walter Fröhlich (Kalamazoo: Cistercian, 1993), 2:229. 
may become more welcoming and compromising towards you."22 In reply to this, Anselm wrote, "By trying to soften the heart of my lord the King towards me because of your desire for my return I perceive that you are doing what is fitting for you and advantageous for him."23 Anselm suggests that Matilda's “good intention” could influence Henry's feelings and behavior, and Matilda indicates that she makes "suggestions" to Henry along these lines. When Anselm states that Matilda's actions are "fitting” for her, he assures her that she is doing exactly what she ought to be in her role as wife of the king. Clearly, both Matilda and Anselm felt that her influence with her husband could do much to mediate the conflict. While most of Anselm's letters to women maintain the "formal posture of male spiritual advisor to that of female suppliant," beneath this was "an exchange of spiritual guidance and encouragement for political support and intercession.”24 Another person who seemed to feel that Matilda's influence on Henry could help resolve the conflict was Pope Paschal II. In 1105, Paschal sent Matilda a letter in which he requests, "we beg you to watch more carefully over his keeping and to turn his heart away from wrong counsel so that he will not continue provoking God's fury so greatly against himself."25 Paschal goes on to say, quoting scripture, “"Reprove, beseech, rebuke.",26

Anselm also sent a letter in 1102 to Clementia of Burgundy, Countess of Flanders. ${ }^{27}$ In this letter, Anselm commends to Clementia

${ }^{22}$ Matilda of Scotland to Anselm of Canterbury, 320, in Letters, trans. Fröhlich, 3:29.

${ }^{23}$ Letters, 321, trans. Fröhlich, 3:30.

${ }^{24}$ Mary Jane Morrow, "Sharing Texts: Anselmian Prayers, a Nunnery’s Psalter, and the Role of Friendship," in Voices in Dialogue: Reading Women in the Middle Ages, eds. Linda Olson and Kathryn Kerby-Fulton (Notre Dame: University of Notre Dame Press, 2005), 103.

${ }^{25}$ Paschal to Matilda, 352, in Letters, trans. Fröhlich, 3:87.

26 Ibid.

${ }^{27}$ Clementia was co-ruler with her husband, Count Robert II of Flanders (1093-1111), and served as regent while he was on crusade. See Biography: 
the actions of her husband, Robert II, for giving over the investiture of abbots to the church in Flanders. There had been a papal decree against lay investitures, and Anselm tells Clementia that he is certain that Robert's actions were due to her influence. He encourages her to continue to influence her husband to right behavior, and that it is her “duty" to do so.

It is your duty, reverend lady and dearest daughter, to mention this and other similar things frequently to your husband 'in season or out of season,' and advise him to prove that he is not lord of the Church, but her advocate, not her step-son but her true son. ${ }^{28}$

Among the popes, Gregory and Paschal were not the only ones to write to women of their duty to influence their husbands, and indeed in some instances the requests were much more specific, and to the personal and political benefit of the pontiff. In a letter to Eleanor of Aquitaine in 1153, for example, Pope Anastasius IV (1153-54) wrote to request Eleanor's assistance regarding a conflict he was having with her new husband, Henry II, shortly before he became King of England (1154-89), regarding the removal and replacement of an abbot of St. Michael. Unlike the letters of Gregory VII, who merely asked the queen to encourage her husband to do good for the Church in a general way, Anastasius' request was more specific.

Since there is a participant of mercy, who shows [her]self a helper in good works, we command, admonish, and exhort your nobility by these writings in the Lord that you strive to suggest to your renowned husband [son] the duke diligently and efficaciously that he permit that abbot to return to his

Clementia of Burgundy, Countess of Flanders, Epistolae, http://epistolae.ccnmtl. columbia.edu/woman/43.html.

${ }^{28}$ Letters, 249, trans. Fröhlich, 2:234. 
Anthós, Vol. VI, Issue 1

monastery in peace and carry out his office in the regular way and do no harm to him about anything or permit harm to be done by his men. ${ }^{29}$

Anastasius apparently decided to get as much help from the women in Henry's life as he could, as he sent this same letter to Henry's mother, Matilda of England. Likewise, in 1162 Pope Alexander III (1159-81) wrote to the Queen of France, Alix of Champagne, in regards to her husband, Louis VII, King of France (1131-80):

May you be zealous ... and labor to so readily encourage and sollicitously confirm ... Louis, illustrious king of the French, your lord and husband, in devotion to St. Peter and us ... that you strive to induce the king and willingly exhort him that he believe without doubt and receive benignly what is proposed to him on our part by them and that, as we hope from him, he not delay to carry it out with useful thoroughness. ${ }^{30}$

In Alexander's request, he encourages Alix to use her power of persuasion and influence over her husband, and by utilizing terms such as "labor," “induce,” and "exhort," the pope emphasizes Alix's responsibility in words that express her role as work - work which she should be doing in service to God.

In an age in which women were generally marginalized, certain women of the nobility and aristocracy had an unusual amount of power, as we have seen. However, even these women had less authority than most men. Undoubtedly, it would have been flattering and personally satisfying for a powerful woman of this period to

${ }^{29}$ Anastasius IV to Eleanor of Aquitaine and Matilda of England, Epistolae, http://epistolae.ccnmtl.columbia.edu/letter/142.html.

${ }^{30}$ Alexander III to Alix of Champagne, Epistolae, http://epistolae.ccnmtl. columbia.edu/letter/250.html. 
receive recognition for her prestige from a man. As many of these women also tended to be highly devout and had a great deal of esteem for the religious leaders of Europe, to receive commendation, praise, and respect from bishops and popes, as well as being asked to put their considerable resources of power to the good of the Church, would be particularly appealing. From the epistolary evidence, it is clear that the members of the episcopate who wrote to these women were well aware of this, and made sure to acknowledge the power of such women in writing. Gregory VII and Peter Damian wrote to Adelaide of Turin and Savoy of her "high rank of office and fullness of power"31 and her "virile strength," respectively. ${ }^{32}$ Anselm of Canterbury wrote to Matilda, Queen of England, regarding "the churches of God which are in your power."33 Additionally, Benzo, Bishop of Alba, wrote several letters to Adelaide of Turin and Savoy, seeking her support for Henry IV (who was also her son-in-law) against the reform program of Gregory VII. In his letters, Benzo rhapsodizes about Adelaide's power, stating, "From childhood, my lady, you do the work of God, therefore with God favoring you will rule after the king of Italy," 34 and "surely it is ordained by divine disposition that you ought to be over peoples and kingdoms,"35 and finally, "the care of the lands of the world are in your hands. For God wishes that you bear the burden of the state with him, who rules the monarchy of kingdoms." 36 Benzo makes sure not only to affirm that Adelaide is a person of significant power, but that she should employ

${ }^{31}$ Register, 1.37, trans. Cowdrey, 42.

${ }^{32}$ Peter Damian to Adelaide of Turin and Savoy, Epistolae, http://epistolae. ccnmtl.columbia.edu/letter/1038.html.

${ }^{33}$ Letters, 346, trans. Fröhlich, 3:75.

${ }^{34}$ Benzo to Adelaide, Epistolae, http://epistolae.ccnmtl.columbia.edu/ letter/1034.html.

${ }^{35}$ Benzo to Adelaide, Epistolae, http://epistolae.ccnmtl.columbia.edu/ letter/1035.html.

${ }^{36}$ Benzo to Adelaide, Epistolae, http://epistolae.ccnmtl.columbia.edu/ letter/1037.html. 
this power for the work of God, and that this is her "burden." It should be noted that Benzo was seeking Adelaide's support for the imperial party through these letters, as opposed to the reformist movement of Gregory VII. This point makes it clear that these methods of obtaining female support during the Central Middle Ages were of general use to the episcopate, and not exclusively employed by reformers.

Along with this type of praise and acknowledgement regarding a woman's ability to wield power in the world, many of these writers would give examples in their letters of famous women from antiquity and from the Bible who were noteworthy for doing something remarkable, as a type of confirmation that women were capable of such things. In the previously mentioned letter to Adelaide, Peter Damian writes of her that, "virile strength rules in a feminine breast," and then proceeds to go on at length with examples of women who accomplished great things in service to God. ${ }^{37}$ In writing to Agnes of Poitou, Gregory VII compares her attempts to mediate between himself and Henry IV to the actions of women from the Bible.

Through you, therefore, as a new example of an ancient joy through you, I say, the women who once sought the Lord in the tomb often return to us in memory. For just as ... they came in advance of the other disciples to the Lord's sepulcher, so with pious love you before many - no, almost before all of the princes of the world visit the church of Christ which is placed, as it were, in the sepulcher of affliction. ${ }^{38}$

Such biblical allegories were also used in defense of the military support of Matilda of Tuscany on behalf of the reforms of Gregory

${ }^{37}$ Peter Damian to Adelaide, Epistolae, http://epistolae.ccnmtl.columbia .edu/letter/1038.html. 
VII, this time not in letters to Matilda, but in other writings of the reformist cause. In various polemics seeking to defend Matilda against her detractors, she was compared to Deborah, Jael, and Judith, and as pointed out by Patrick Healy, "Biblical allegories of this kind served ... to present Matilda in a biblical tradition of strong female leadership."39

As has been mentioned above, the letters from bishops to noble women often utilized vocabulary of "work" or "labor." Gregory spoke to the Empress Agnes of "the light of your endeavor," and "the fruit of your toil," and assured her that, "so that it might rise once more to the state of its liberty, you are striving with all your powers, and as if instructed by angelic responses you are arousing others to the help of a struggling church." ${ }^{\prime 0}$ Peter Damian requested of Adelaide of Turin, "bestow the vigilant watches of your protection [on the monastery of Fruttuaria]." ${ }^{\prime 1}$ To Matilda of Scotland, Hildebert, the Bishop of Lavardin directed, "Be attentive, I say, to how your artificer labored over you and labor so that his labor not deteriorate." ${ }^{\prime 2}$ Gregory VII was so dependent on Matilda of Tuscany's support utilizing all of her "worldly" power (as opposed to her spirituality) that he even convinced her not to become a nun after the failure of her marriage: ${ }^{43}$

For if ... there were one who might assist the miserable and oppressed churches in your place, and serve the universal

${ }^{38}$ Register, 1.85, trans. Cowdrey, 90.

${ }^{39}$ Patrick Healy, "Merito nominetur virago: Matilda of Tuscany in the Polemics of the Investiture Contest," in Victims or Viragos?: Studies on Medieval and Early Modern Women 4, eds. Christine Meek and Catherine Lawless (Dublin: Four Courts Press, 2005), 55.

${ }^{40}$ Register, 1.85, trans. Cowdrey, 89.

${ }^{41}$ Peter Damian to Adelaide of Turin, Epistolae, http://epistolae.ccnmtl. columbia.edu/letter/1038.html.

${ }^{42}$ Hildebert to Matilda of Scotland, Epistolae, http://epistolae.ccnmtl. columbia.edu/letter/415.html. 299.

${ }^{43}$ H. E. J. Cowdrey, Pope Gregory VII 1073-1085 (Oxford: Clarendon, 1998), 
church, I would take pains to advise you to leave the world with all its cares. But since you do not, like many princes, cast God out of your hall, but rather invite him to come in with the sacrifice of justice, we ask you and admonish you as dearest daughters to bring the good which you began to its full conclusion. ${ }^{44}$

In this letter, Gregory makes it clear to Matilda that while he would normally encourage her to enter into the religious life, the Church is in trouble and needs her help, and there is no one else who can adequately perform this service.

Members of the clergy who hoped to gain assistance from the power of noble women in political dealings with the nobility were also careful to promote this power by the use of flattery and words of love. Bishops' letters to pious women who could serve the Church were expansive in their praise. Indeed, many of the letters from monks, bishops and popes to powerful laywomen often sound more like love letters than messages from "spiritual leaders" to their "daughters in Christ." Benzo, Bishop of Alba, wrote to Adelaide of Turin, "You are full of graces, your eyes of doves; go after him who is the God of mercies," 45 and Peter Damian begs the Empress Agnes to return to Rome from the German court in dramatic fashion: "I can scarcely say how my heart is confounded with grief while it awaits the happiness of your return daily with my entrails in suspense." ${ }^{\text {46 }}$ Even the normally more reticent Anselm of Canterbury, in writing to his good friend Ida of Lorraine in 1093 during a particularly difficult time for him, ${ }^{47}$ displays a significant amount of affection, writing,

${ }^{44}$ Register, 1.50, trans. Cowdrey, 56.

${ }^{45}$ Benzo to Adelaide of Turin and Savoy, Epistolae, http://epistolae.ccnmtl. columbia.edu/letter/1036.html.

${ }^{46}$ Peter Damian to Agnes of Poitou, Epistolae, http://epistolae.ccnmtl. columbia.edu/letter/133.html.

${ }^{47}$ For more on the significance of the timing of this letter and Anselm's confidence in, and friendship with Ida, see Sally Vaughn, Handmaidens, 133-134. 
"lady dearest to me in God, most beloved sister, sweetest daughter that your holy love, by which you ever embrace me reverently and affectionately in your heart as if I, your spiritual father, were present."48

As mentioned above, Gregory VII was particularly known for using "the vocabulary of love and friendship" in his correspondence with both men and women, lay and clerical alike. ${ }^{49}$ The principal recipient of Gregory's papal friendship letters, however, was the Countess Matilda of Tuscany, as well as her mother Beatrice. ${ }^{50}$ In any study of the clergy's access to female power during this period, the most noticeable and widely discussed in the historical record surely involves la gran donna d'Italia. Matilda owned vast swaths of land in northern Italy as the sole living heir to her father, Boniface III, Margrave of Tuscany. Thanks in part to her mother's second marriage to Godfrey the Bearded, and Matilda's own subsequent marriage to his son (her step-brother) Godfrey the Hunchback, she also had strong territorial claims to Lotharingia, and a great deal of influence over the clergy in that area. ${ }^{51}$ After the deaths in 1076 of both her mother and her husband, Matilda came into what Jennifer Lawler calls, "her formidable inheritance: her parents' northern-Italian domains and her husband's in Lorraine ${ }^{52}$ so that her lands extended to both sides of the Alps and Appenines."53 In addition to writing many letters herself in support of Gregory's campaign of reform, she also provided the papal

${ }^{48}$ Letters, 167, trans. Fröhlich, 2:62.

${ }^{49}$ I. S. Robinson, “The Friendship Network of Gregory VII,” History, 63, no. 207 (1978): 8.

${ }^{50}$ Ibid., 10.

51 Ibid.

52 Another name for Lotharingia.

53 Jennifer Lawler, ed., "Matilda of Tuscany," in Encyclopedia of Women in the Middle Ages (Jefferson: McFarland, 2001), 630. 
cause with significant economic assistance, and provided Gregory's primary military support. ${ }^{54}$

Gregory's relationship with Matilda was somewhat different than his friendships with other noble women. Matilda was in possession of much more power - politically, economically, and most importantly, militarily - than most women of her era. As such, Gregory's friendship with Matilda was more akin to one he would have had with a man in her position, and indeed, he often referred to her and her mother with the masculine "duke" $(d u x)$ rather than the feminine form "duchess" (ducatrix). Likewise, his letters often go into more particular matters of policy and politics than he would with most other women, while still displaying a great deal of the warmth of their friendship. Although Matilda was married to Duke Godfrey during Gregory's lifetime, there are no examples of Gregory requesting Matilda to use her influence on her husband. In part, this is likely because the marriage was not a happy one and the couple soon separated. However, it is just as likely that Gregory felt he had a sufficiently worthy ally in Matilda alone.

From the very beginning of Gregory's pontificate, the Countesses of Tuscany "identified themselves with the plans of Gregory VII,"55 attending the Roman synods and promoting the reform in their own territories. $^{56}$ Gregory also had a great deal of support from the Empress Agnes of Poitou, the mother of his adversary Henry IV. This level of personal involvement between a Roman pontiff and various women was looked on with suspicion by Gregory's detractors, as evidenced by the reference to a "senate of women" complained about by the German bishops at the Lenten Synod of 1075, mentioned at the beginning of this writing. "The close relationship between Pope Gregory and Matilda from the start of his

${ }^{54}$ Ibid. See also Demetrius B. Zema, "The Houses of Tuscany and of Pierleone in the Crisis of Rome in the Eleventh Century,” Traditio 2 (1944): 157-165.

55 Zema, Houses, 159.

56 Ibid. 
pontificate provided much scope to slander the pope,"57 asserts Patrick Healy. Gregory himself was aware of the disdain his contemporaries had for such relationships, as were the other clerical writers who corresponded with powerful lay women. Some epistolary evidence of the concern these men had for the perceived impropriety of their friendships with women can be seen in the correspondence itself. Peter Damian, unsurprisingly, was one who had concerns about how his relationships with women would be viewed by other members of the clergy. In a 1064 letter to Adelaide of Turin he states:

I had determined to write to you before, except that I feared the malicious reaction of those insulting clerics. For they would expostulate and say: Behold, how impiously, how inhumanly this one prepares to confound us who wishes to speak not cautiously and modestly with bishops, nor with ecclesiastical men about our business, but what should be treated in a sacristy he does not fear to publish to women. Fearing this, I changed the person, and what I had intended for you, I sent rather to him. ${ }^{58}$

In a letter of 1074, Gregory acknowledges the clerical grumbles which were just beginning in a letter to Beatrice and Matilda: "It has not escaped you that reports of various kinds about you are often brought to us as is the way of those jealous of the love and unanimity of friends." ${ }^{59}$ In his extensive monograph of Gregory, the historian $\mathrm{H}$.

${ }^{57}$ Healy, "Merito," 55.

${ }^{58}$ Peter Damian to Adelaide of Turin, Epistolae, http://epistolae.ccnmtl. columbia.edu/letter/1038.html. The "him" referred to is the Bishop of Turin. In this letter, Damian is asking Adelaide to work with the bishop to end clerical marriage in Turin.

${ }^{59}$ Register, 2.9, trans. Cowdrey, 103. 
E. J. Cowdrey argues that, after the famous humiliation of Henry at Matilda's castle of Canossa: ${ }^{60}$

Gregory had grown in discretion. Stung, no doubt, by the propagandist calumnies fuelled by Hugh Candidus in 1076 about his political and personal relations with women and especially the devote Countess Matilda of Tuscany, still in her prime and separated from her husband, Gregory gave no more pretext for mockery and gossip. Pious women played no such part as they had hitherto played in his plans ... No longer did Gregory write to Matilda in terms of personal closeness and familiarity. ${ }^{61}$

Cowdrey also suggests that Gregory's caution may have had something to do with the fact that he was now working with Matilda alone rather than together with her mother. "While Countess Beatrice lived," he argues, "Gregory took no apparent notice [of accusations of scandal] and continued to treat her and her daughter as close advisers and confidantes." ${ }^{22}$ Both Matilda's mother and her husband, Godfrey the Hunchback, had died in 1076. This left Matilda to rule her territories alone, and thus at the height of her personal power. ${ }^{63}$ But she was also no longer married, adding to the impression of impropriety in her close relationship with Gregory. After 1077, there is only one letter in the record from Gregory to Matilda, and it is

${ }^{60}$ In 1077, Henry stood in the snow outside Canossa, where Gregory was staying, for three days in penitence, and was absolved by Gregory, who had excommunicated him. See Cowdrey, Pope Gregory VII 1073-1085, 153-167.

${ }^{61}$ Cowdrey, Pope Gregory, 166-167.

62 Ibid., 300.

${ }^{63}$ Godfrey the Hunchback was actually murdered in Holland in February, 1076. According to contemporary chroniclers, just before his death he designated his nephew, Godfrey of Bouillon, as his heir. For more on how his territories ended up under the control of his estranged widow, Matilda of Tuscany, instead, see John C. Andressohn, The Ancestry and Life of Godfrey of Bouillon (Bloomington: Indiana University, 1947), 18 and 34-35. 
noticeably cooler in tone than his prior correspondence with her. ${ }^{64}$ Considering Matilda's continued efforts on behalf of the Roman see, however, it is clear that her devotion to the papal cause had not cooled in response. Even after Gregory's death in 1085, Matilda continued to support his successors, Paschal II and Urban II, in their continued efforts for reform, including making a marriage alliance with a man twenty-six years her junior at the behest of Pope Urban. ${ }^{65}$

The number of women of the eleventh and twelfth centuries who wielded any power in the male-dominated, decidedly misogynistic world of the Central Middle Ages was very small and select. However, many of those who were a part of that group possessed powers that were strong enough to override the general disdain of men towards female agency. Significantly, the clergy, the very group producing the majority of misogynistic literature, also made the attempt to access this female power to their own ends. Their methods of securing the support and assistance of eminent women involved utilizing vocabulary which acknowledged the personal power and prestige of these women, expressed the employment of their power as a sacred duty, and utilized the vocabulary of love and friendship.

For the purposes of this examination we have focused specifically on the eleventh and twelfth centuries. In a cursory glance at the letters that exist from the previous and subsequent centuries, one occasionally sees the same types of themes in the correspondence between the clergy and noble women. Upon casual review, however, the numbers of such letters seem much smaller. Perhaps the ability of women to wield such significant power was exclusive to this period of time? Or perhaps an argument could be made that the episcopate more actively pursued a program of enlisting alliances with powerful women during this period of political upheaval between secular and

${ }^{64}$ Healy, "Merito," 55.

${ }^{65}$ Zema, "Houses of Tuscany," 167. At the age of 43, Matilda married the 17 year old Welf V of Bavaria to block Henry's passage across the Alps. See also Nora Duff, Matilda of Tuscany: la Gran Donna d'Italia, 190-198. 
clerical powers? The amount of power which was in the hands of secular ruling men was greater than that of either lay women or the clergy alone. But for the clergy, making alliances with the handful of very powerful women may have been seen as an attempt to even the balance. A great deal more research would need to be conducted in order to answer these questions.

One of the primary requests that members of the episcopate made of noble women in the eleventh and twelfth centuries was in the influence of their husbands and sons, who were generally among the highest ranks of the nobility - dukes, counts, kings, and even emperors. As Sharon Farmer argued in her study of clerical images of medieval wives, "perceptive and practically minded churchmen wanted to encourage women to influence their husbands." ${ }^{66}$ As we have seen, however, the episcopate asked for, and received, far more from these women than just their influence with their husbands. Because of the power that some of these women had - politically, economically, and militarily - they had a great deal more to offer in service to the Church. Women such as the Empress-Dowager Agnes of Poitou, the Countesses Beatrice and Matilda of Tuscany, Countess Adelaide of Turin and Savoy, and the Queen of England, Matilda of Scotland, provided their considerable support and resources in the major conflict of the Middle Ages known as the Investiture Controversy, by serving as mediators and occasionally providing economic and/or military support. Through the letters sent to these powerful women by members of the episcopate, we can clearly see that the clergy was not only well aware of the fact that these women possessed great power, despite the generally low opinion of women generally, but that these religious men were not averse to harnessing that power in any way that they could in service to the Church.

${ }^{66}$ Sharon Farmer, "Persuasive Voices: Clerical Images of Medieval Wives," Speculum, 61, no. 3 (1986): 521. 


\section{Bibliography}

\section{Primary Sources}

Anselm of Canterbury. The Letters of Saint Anselm of Canterbury, Volumes 1-3. Translated by Walter Fröhlich. Kalamazoo: Cistercian Publications, 1994. Epistolce: Medieval Women's Latin Letters, compiled by Joan Ferrante.

http://epistolae.ccnmtl.columbia.edu/.

Gregory VII. The Register of Pope Gregory VII 1073-1085. Translated by H. E. J.

Cowdrey. Oxford: Oxford University Press, 2002.

Secondary Sources

Andressohn, John C. The Ancestry and Life of Godfrey of Bouillon. Bloomington: Indiana University, 1947.

Blumenhal, Uta-Renate. The Investiture Controversy: Church and Monarchy from the Ninth to the Twelfth Century. Philadelphia: University of Pennsylvania Press, 1988.

Canatella, H.M. "Friendship in Anselm of Canterbury's Correspondence: Ideals and Experience” Viator 38, no. 2 (2007): 351-367

Cowdrey, H. E. J. Pope Gregory VII: 1073-1085. Oxford: Clarendon Press, 1998. Duff, Nora. Matilda of Tuscany: la Gran Donna D'Italia. London: Methuen, 1909. Farmer, Sharon. "Persuasive Voices: Clerical Images of Medieval Wives."

Speculum 61, no. 3 (1986): 517-543.

Ferrante, Joan M. To the Glory of Her Sex: Women's Roles in the Composition of Medieval Texts. Bloomington: Indiana University Press, 1997.

- "Letter Writing." In Women and Gender in Medieval Europe, an Encyclopedia, edited by Margaret Schaus. New York: Routledge, 2006.

Healy, Patrick. "Merito nominetur virago: Matilda of Tuscany in the Polemics of the Investiture Contest.” In Victims or Viragos?: Studies on Medieval and Early Modern Women 4, edited by Christine Meek and Catherine Lawless, 49-56. Dublin: Four Courts Press, 2005.

Lawler, Jennifer, ed. Encyclopedia of Women in the Middle Ages. Jefferson: McFarland, 2001.

LoPrete, Kimberly A. “Noble Women.” In Women and Gender in Medieval Europe, an Encyclopedia, edited by Margaret Schaus. Routledge, 2006.

McNamara, Jo Ann, and Suzanne Wemple. "The Power of Women Through the Family in Medieval Europe: 500-1100.” Feminist Studies 1, no. 3/4 (1973): 126-141.

Mommsen, Theodore E., and Karl F. Morrison. Translated by Imperial Lives and Letters of the Eleventh Century. New York: Columbia University Press, 2000. Morrow, Mary Jane. "Sharing Texts: Anselmian Prayers, a Nunnery’s Psalter, and 


\section{Anthós, Vol. VI, Issue 1}

the Role of Friendship.” In Voices in Dialogue: Reading Women in the Middle Ages, edited by Linda Olson and Kathryn Kerby-Fulton, 97-113. Notre Dame, Indiana: University of Notre Dame Press.

Robinson, I. S. “The Friendship Network of Gregory VII.” History 63, no. 207 (1978): 1-22.

Triebs, Carl R. "About Celibacy, I Have No Instructions From the Lord”: An Inquiry Into the Origins of Clerical Celibacy. Victoria, BC: Trafford, 2004. Vaughn, Sally. St. Anselm and the Handmaidens of God: A Study of Anselm's Correspondence with Women. Turnhout: Brepols, 2002.

Zema, Demetrius B. "The Houses of Tuscany and of Pierleone in the Crisis of Rome in the Eleventh Century.” Traditio 2 (1944): 155-175. 